Article

\title{
Why Young Adult Believers Are Turning Away from Religions: With a Focus on Religious Congregations in Downtown Seoul
}

\author{
Francis Jae-ryong Song \\ Department of Sociology, Kyung Hee University, Seoul 02447, Korea; jrsong@khu.ac.kr
}

Received: 15 July 2019; Accepted: 18 August 2019; Published: 22 August 2019

\begin{abstract}
The sociological study of youth religion is a growing field of research. This essay focuses on the rising number of young Korean adult believers from five downtown religious congregations in Seoul who are leaving their congregations due to increased cynicism and as they re-examine their religious faith. Based on a series of in-depth interviews (Focus Group Interviews (FGIs)) conducted with both young adult believers and priests, this paper examines several key factors including why young adult believers decide to leave their congregations, how their congregations react to the changing environment, and whether they can develop innovative approaches to deal with the emerging situation. Although each and every one of the congregations considers this phenomenon to be a serious issue, the solutions they have applied to retain and attract young adult believers in and to their faith have so far been ineffective. Nonetheless, it is likely that the reason behind the failure to keep more young adults in their faith and congregation may correlate to how competitive and innovative solutions provided by the congregational leadership are as they attempt to tackle the ongoing issue of retaining and attracting young adult congregational members.
\end{abstract}

Keywords: young adult believers; religious congregation; religious economies theory; Confucian habits of the heart

\section{Introduction: Research Interests and Perspectives}

According to the '2015 Population and Housing Census Report' (PHCR) released by Statistics Korea (2017), ${ }^{1}$ the largest religious group comprising 19.7 percent of the Korean population was Protestant, followed by Buddhists who comprised 15.5 percent, and Catholics at 7.9 percent. Combined with other minor religions, the proportion of religious believers stood at 43.9 percent of the total population. Meanwhile, the proportion of non-religious believers totaled 56.1 percent, marking a significant increase from 47.1 percent based on the census conducted back in 2005.

The rising trend of non-religiosity is especially pronounced among young adults. As seen in the figures below, the nationwide survey conducted by KGSS ${ }^{2}$ indicates a gradual upward trend of young adults, whose age ranged from 18 to 39 , who identified as non-believers since the early part of the new millennium. ${ }^{3}$ As Figures 1 and 2 illustrate, the population of young adult non-believers both nationwide and from Seoul Metropolitan areas reflects a gradual but clear sign of a 'steady upward trend' since 2007. It should be noted that the increasing trend of non-religiosity among young adults rose sharply in 2016.

Statistics Korea (http://kostat.go.kr).

Korean General Social Survey (http://kgss.skku.edu).

The 'non-religious' cohort, measured by both 'PHCR' and 'KGSS', is based on the conventional questionnaire method of whether a respondent belongs to a particular religious organization, not whether he or she has real religious or spiritual belief, even if not belonging. 


\section{(Non)religious trends nationwide among young adults}

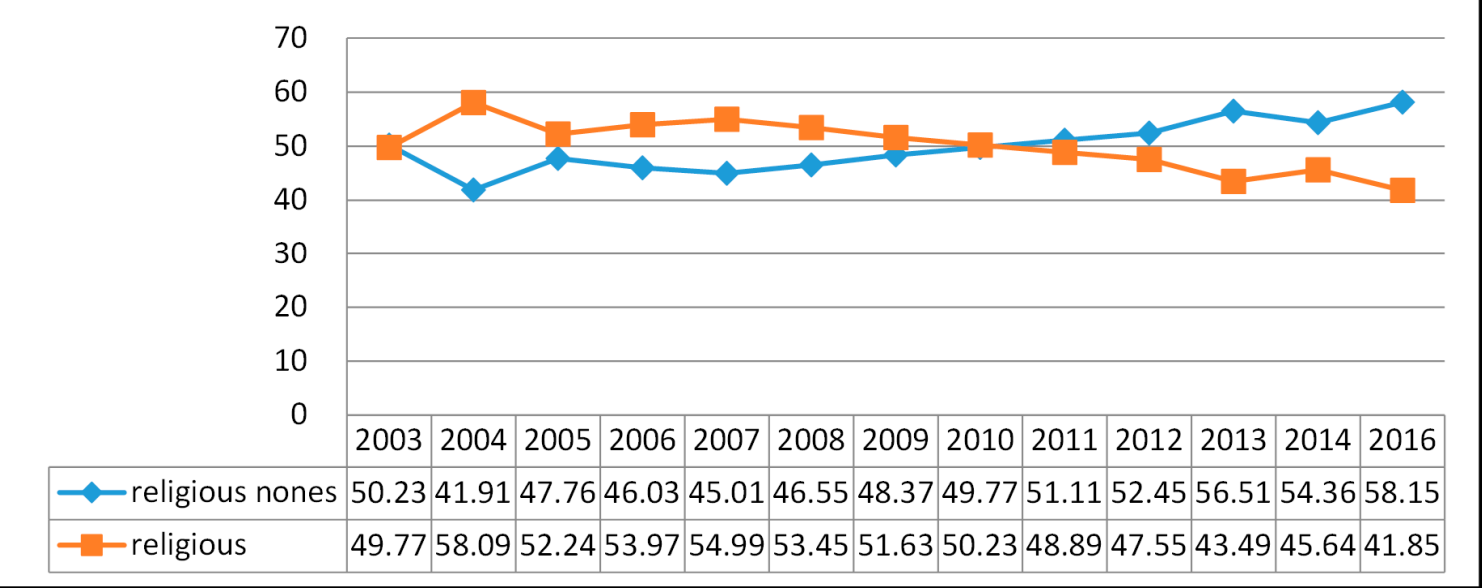

Figure 1. Nationwide trends among young adults (aged 18-39): 2003-2016. (\%). Source: Korean General Social Survey (KGSS) 2003 2016.

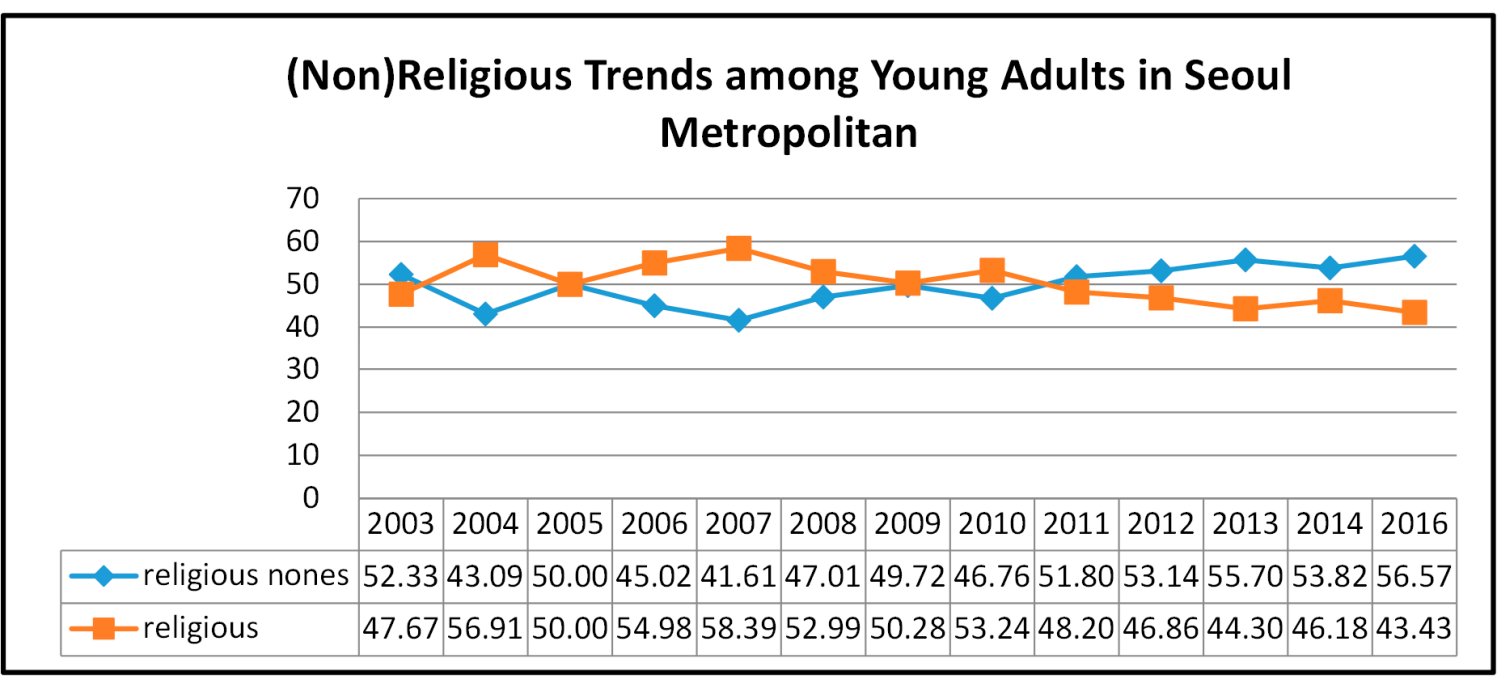

Figure 2. Trends among young adults in Seoul Metropolitan: 2003-2016. (\%). Source: KGSS 2003 2016.

Recently, a number of sociological studies have been conducted on why young adults in various societies around the world are turning away from their religious faith (Fischer and Hout 2006; Giordan 2010; Mason et al. 2007; Woodhead 2017). Generally, sociologists of religion tend to focus primarily on the interaction between the rise and fall of young adults' religiosity and the process of modernization, individualization and globalization, in addition to their joint relationships with other important variables. Research findings mostly reveal that the lives of young adults have been profoundly affected by contemporary socio-cultural situations such as postmodern relativism, individualism, globalism, free-market capitalism, and so on (Collins-Mayo 2012; Fulton 2000; Hoge 2001; Woodhead 2017).

This perspective is also adopted in a recent work by Putnam and Campbell. In their American Grace, Putnam and Campbell use the generational analysis to investigate America's religious trajectories of the past half century (Putnam and Campbell 2012). The authors state that the key causal factor in the surge of young adult religious "nones" since the 1990s, who account for one-quarter of the young adult generation in the US, is closely related to the 'generational change' much influenced by postmodern cultural relativism. Putnam and Campbell argue that young adult religious nones see 
religion as influenced by conservative political ideas especially when dealing with issues like abortion and gay marriage and, as a result, their aversion to the latter has led them to reject the former (op. cit., pp. 91-133).

Undoubtedly, these studies have convincingly proven the vital effects of macro factors on the non-religiosity of young adults in contemporary society. However, it seems insufficient to rely solely on the effects of macro factors to explain why young adult believers ('YABs' hereafter) are abandoning their faith or congregations in certain societies. In this context, applying a macroscopic approach to gain a reflexive understanding of the in-depth and multidimensional situation surrounding the Korean religious economy, which is profoundly connected to the cultural disposition of Korean society, seems unlikely to produce a comprehensive and satisfactory outcome. Consequently, it appears to be logical to observe these dimensions from a micro perspective.

Recent field research by Bowen regarding the fluctuating number of young adult Christians leaving their faith approaches this subject matter from a micro point of view. Bowen argues in his book Growing Up Christian that the reason young adults leave the church is primarily because the experiences they encountered through activities surrounding the church or places of worship have been generally unsatisfying (Bowen 2010). Specifically, lack of open-mindedness and tolerance about various social issues and perspectives, lack of a participating spirit for practicing the common good, and lack of innovative efforts to bring changes in worship services resulted in YABs feeling disconnected from their church and faith.

Similarly, through his studies, Jeon, a Korean researcher, reveals four reasons why more and more young Korean Christians are losing interest in their faith and unwilling to attend church services. He highlights how obsessed churches in Korea are in general with emphasizing the importance of structural elements like success supremacism, privatized faith, exclusiveness, and authoritarianism (Jeon 2017). Jeon argues that, among these four, the 'authoritarian factor' is actually the greatest obstacle preventing Korean churches from pursuing innovation. In fact, the authoritarianism prevalent throughout the church community creates an undemocratic environment that solely emphasizes the obligations of YABs without recognizing many of their rights. Such behavior has consequently failed to nurture interactive and democratic ways to communicate for the young adult believer generation. Naturally, this hinders young people from participating freely and actively in their church's decision-making process.

U.S. researcher David Kinnaman applied a detailed micro-level approach to understand the non-religious tendencies of YABs. Using an in-depth interview method, Kinnaman examined in his book You Lost Me why many young adult Christians grow frustrated with their church and end up deserting faith and leaving church communities behind (Kinnaman 2011). Having presented three broad category types of 'nomads', 'exiles' and 'prodigals,' Kinnaman paid attention to the perceptions of young adult Christian believers who regard the church to be overprotective, shallow, anti-scientific, judgmental, exclusive, and doubtless (Kinnaman 2011, pp. 95-199).

In particular, Kinnaman uncovered two cultural background factors that explain why YABs identify the church in terms of the six unfavorable qualities mentioned above. They are the traditional view of young adults in 21st-century American society, and a hierarchical top-down approach by the church in dealing with the younger generations. According to Kinnaman, most churches tend to work best for 'traditional' young adults whose life journeys and life questions are universal and conventional to the ways of the past. However, many young adults in present-day society no longer subscribe to the typical and familiar path of leaving home, getting an education, finding a job, getting married, starting a family, and so on. Also, many churches continue to resort to the traditional hierarchical top-down approach when dealing with the young generation of believers without supplying a true team of believers that can appeal to the interests of all generations.

What both Jeon and Kinnaman focus on has a lot to do with the 'cultural disposition' of the church community and its effects on the structure of the religious economy. This has important implications for the theme of this paper. 
Taking into consideration the possibilities and limitations of the theme to be reviewed, this essay attempts to examine the ups and downs of religious faith among YABs belonging to religious congregations in the downtown Seoul area. It first focuses particularly on the growing number of YABs who are leaving their congregations and are either thinking twice about their faith or abandoning it completely. It then examines why YABs decide to leave their congregations, how their congregations react to the evolving changes resulting from the departure of YABs, and whether church communities attempt to create innovative measures to deal with this problematic situation.

For my research, I chose to concentrate the scope of my field primarily on five downtown religious congregations in Seoul, namely, 'Youngnak Presbyterian Church,' 'Seoul Anglican Cathedral,' 'Myeong Dong Catholic Cathedral,' 'Bulkwang Buddhist Temple, ${ }^{4}$ and 'Cheondogyo Seoul Diocese. ${ }^{5}$

As implied above, the basic assumption of this study concerns the theory of religious economies. The phenomenon of religious congregations attempting to retain their congregants, like so much else in any society, reflects the logic of a competitive ecosystem. Similar to how economic businesses compete for customers, religious congregations compete to attract their members. And larger numbers of congregants are usually considered an indicator for gauging the success of a religious organization. In the course of this competition, the focus is macroscopically on changes in the supply side.

However, there is another aspect that should not be overlooked in regard to the religious competitions and innovations in Korea. As implied in the approaches applied by both Jeon and Kinnaman, an understanding of this aspect is related to the perspective concerned with the sociological understanding of culture, which focuses usually on the cultural dispositions that operate on the collective level in a society. This dimension is significant in understanding the religious economies of believers as not atomistic individuals, but rather as collective beings under cultural influences. This approach complements the limitations of the religious economies theory, which places less importance on the significance of the cultural dimension as a source or background of the 'religious demand-side' by prioritizing the 'supply side of religion' (Song 2013). A further discussion on this topic follows below.

\section{Religious Economies Theory and Its Complementary Perspectives}

As such, existing sociological studies have paid less attention to the internal factors between religions or congregations affecting the (non) religiosity of young adults. In particular, there have been few studies on competition, innovation, and spiritual progress between religions or congregations. Religious economies theory assumes that, as in the economic market, conditions of a competitive religious market provide high quality 'supplies' and, just like high quality goods, these supplies are appealing to religious buyers. Therefore, in such a situation, competitive religions or congregations stimulate potential buyers' religious participation and thus lead to the survival or revival of religions or congregations (Finke and Stark 1992; Inglehart and Norris 2007, pp. 254-55; Lechner 2007; Stark 2006, pp. 47-68; Stark and Finke 2000, pp. 193-258; Yi 2014; Yoo 2014).

Religious economies theory asserts that human demand for religion remains historically constant. Otherwise known as the 'supply side theory,' it emphasizes 'supply' rather than 'demand' as a determinant of the religious market. Therefore, the characteristics of the religious markets are determined by 'changes in supply.' In other words, changes in the supply-ide, which can define a

4 In the early stages of the research, the author chose 'Jogye-sa' in the Seoul downtown area, but the Buddhist temple refused to accept the author's in-depth interview request due to a politically sensitive conflict within Jogye-sa that arose during this time. As a result, 'Bulkwang Buddhist Temple' was selected as the alternative-a temple which was established in downtown Seoul in 1974 and moved to the Seoul Gangnam area in the early 1980s.

5 Cheondogyo is a religion that began during the last years of the Joseon Dynasty. It began in 1860 with Donghak, or Eastern Learning, founded by Choe Je-U. Its name was changed to Cheondogyo in 1905 by the third leader of the church, Son Byeong-Hui. The fundamental doctrine of the religion teaches that man is God because God is both transcendent and immanent in Heaven, Earth, and Man; that all human beings are equal; and that when one dies, one does not go to some other-dimensional heaven but returns to the One Being. 
particular religion as a national religion or restrict a particular religion, vary according to variables like age and society. For example, in a social environment where religion is regulated by the state, it will be difficult to create a free religious market that satisfies diverse needs and, subsequently, activating a religion will be a challenge. Meanwhile, if religion is not regulated by the state, religious markets are likely to be created to meet various needs and religion is activated through competition with other religions to attract more believers. The core proposition of religious economies theory is that 'religions flourish where there are religious competitions.' In other words, 'where there is no religious competition, religion declines.'

However, there are religious phenomena that go against this proposition. That is, there are circumstances where certain religions do not decline but thrive even in monopolistic conditions. A typical example of this is found in Muslim countries in the Middle East where Islam is monopolistic but thrives exclusively. Another one is European Catholic countries like Italy, Ireland and Poland, and Latin American Catholic countries like Colombia, Venezuela and Brazil, where Catholicism has remained very strong despite its almost monopolistic status (Norris and Inglehart 2004, p. 12; Song 2013, pp. 120-21). ${ }^{6}$ In any case, these examples reflect the limitations or difficulties facing the supply side theory in practical terms.

In addition, there are also discussions about the conceptual or theoretical limitations of the religious economies theory (Bush 2010; Chen 2014; Stolz 2006). Based on the idea of the religious symbol system, Stolz views religions as institutionalizing various types of religious goods. According to Stolz, there are diverse types of religious goods that consist largely of individual and social religious goods. These diverse types of religious goods develop markets where they are produced, exchanged and allocated. Stolz argues that the concepts of 'religious goods' and 'religious markets' should be integrated into a larger theoretical framework (Stolz 2006, pp. 12-30), thus enabling sociologists of religion to understand the complexity of the production and allocation of religious goods, which the existing religious economies theory tends to ignore.

Meanwhile, by dissecting the legal components of the religious free market, Chen raises serious questions about the normative value of the religious free market. She argues that the complex dynamics between the various legal components like the Establishment Clause and the Free Exercise Clause can materially affect the condition of the religious market where the level of 'free competition' varies (Chen 2014, pp. 19-24). What Chen suggests here is that the notion of the religious free market as a core premise of the religious economies theory should be further complemented and developed.

By ignoring these dimensions, a picture of religious markets is usually depicted as free, even when in fact they are predetermined. This is clearly examined in Bush's work on the gendered discrepancies of the religious markets. Bush points out that while women's levels of religious participation and commitment are disproportionately high relative to that of men, the gender ideologies promoted by most religions tend to favor men's interests over women's interest. He argues that religious economies theory fails to take into account several restrictive gender-related factors that determine the supply of religion (Bush 2010, pp. 319-23). Bush, in suggesting three modifications to the theory, contends that religious economies theory needs to be more critically analytical in examining the supply side of the religious economy.

All of the critical discussions mentioned above reveal the shortcomings of religious economies theory. But they suggest that the religious economies theory should and could be supplemented in conceptual and theoretical terms, instead of abandoning it as a tool for understanding religion. With regard to sociological understanding of religion, as Bush emphasizes (Bush 2010, p. 323), any religious economies approach needs to be more reflexively critical in order to better examine the

6 As of 2011, Catholicism occupies a monopolistic status in the religious distribution in these countries. The proportion of Catholics versus members of other religions is, respectively: 97:3 in Italy, 94:6 in Ireland, 97:3 in Poland, 85:15 in Venezuela and 70:30 in Brazil (Pew Research Center 2011). 
limitations on religious rational choice and the free market's failure to produce a sufficient diversity of options.

In particular, these limitations or problems of the religious economies theory seem to arise from its relation to the social and cultural characteristics of a particular society. This point is echoed very well in Yang's critique of the religious economies theory in terms of his idea of a triple religious market (Yang 2006; Yang 2012). Yang's sociological understanding of religion is primarily associated with religious economies theory but is critically complemented by a multi-layered perspective on religious phenomena in China. He observes that a religious supply model based on a Western-centric unilinear view on religion has a limit in explaining the multi-layered dimension of religious phenomena in China. Thus, Yang, following Janos Kornai's hypothesis on the shortage economy theory, focuses more importantly on the demand-side of a religious economy.

Based on this perspective, Yang believes that the religious shortage economy, caused by the result of the Chinese Communist Party's legal restrictions on religion, has led to an unusual expansion of the oligopoly religious market structure and the gray market situation. ${ }^{7}$ And it resulted in a socio-cultural environment where numerous new religions, which were stigmatized as 'a quasi-religion', 'a semi-religion', or 'a pseudo-religion', have grown (Yang 2012, pp. 85-122, 123-58). He goes further to argue that the oligopoly religious market situation becomes more and more prevalent in the modern pluralist world, so that the sociological perspective of oligopoly can be actively adopted to reflexively understand the dynamics of religion-state relations and religious changes in societies (ibid., pp. 159-79).

While Yang's critical discussion of the religious economies theory was made from a macro-level analysis on religion in both China and the world, there is a recent case study with a micro perspective on the status of religious competition in Korea Protestantism. (Yi 2014). Yi's studies have shown that the noticeable growth of the Korean Protestant church can, in part, be understood clearly in terms of competition between churches rather than between religions or denominations. Yi presupposes that the urbanization process has directly affected the mission strategy, education, and social functions of the religious market and, as a result, it has become a major requirement for the expansion of the Protestant religious market in Korean society. That is, the Protestant Church, which has been highly sensitive to the urbanization process and its subsequent spatial reorganization, has succeeded in constructing a missionary strategy to meet the daily basic needs of people created by regional (re)development, population movement, and changes in industrial structure. Yi especially argues that the Korean Protestant churches, going beyond the demarcation between the sacred and the profane, have created new demand in the urbanization process in combination with basic livelihood essentials such as welfare, education and relief (Yi 2014, pp. 253-54).

Yi's study is distinctive in two aspects. It attempts to explain the supply-side factors of the religious market, in a way that pays attention to inter-church competition instead of inter-religious competition or state intervention. The conventional theory of religious economies focuses generally on inter-religious and denominational competition. But the theory acknowledges that competition can occur among the churches within Protestantism. At the same time, it assumes that non-religious secular demand may affect the religious supply side. That is, changes in the daily essential needs of people lead to changes in the supply side of religion, which in turn creates new religious demands. This is quite different from the religious economies theory, which assumes religious demand-the 'desire for religiosity' —remains constant.

In a nutshell, this suggests that a more reflexive understanding of religious status in Korean society should be approached on a micro level based on which competitions between churches or congregations can be examined. Subsequently, examining macro factors such as competitions between

7 The grey religious market is central in his idea of a triple religious market situation. According to Yang, it includes all religious and spiritual organizations, practitioners, and activities that have an ambiguous legal status, and that has been largely neglected in studies of religion, especially the religious economic approach developed from a Western-centered view (Yang 2012, pp. 120-21). 
religions or denominations as emphasized in orthodox religious economies theory appears to be less effective for gaining a better understanding, and such a finding has significant implications for this essay.

There is, however, a flip side to this reality that should not be overlooked in regard to the religious competitions and innovations in Korea. This is the aspect of cultural disposition, which persistently influences the process of survival and prosperity which enables religion to maintain its dominance in Korea, and this is especially true for Christianity. Following Robert Bellah's concept of 'habits of the heart' and Wittgenstein's 'forms of life' (Bellah et al. [1985] 1996; Wittgenstein 1953), Korean society is believed to have been deeply influenced by the Confucian habit of the heart inherited from the neo-Confucian legacy of the Joseon dynasty (Ivanhoe and Kim 2016; Song 2002, 2009). The Confucian habit of the heart has given rise to a strong 'cultural disposition' that determines the collective life of the Korean people, but in a way that also drives the Korean mindset to follow a specific 'form of life' characterized by the hierarchically-oriented collective behavior (Chae 2014; Song 2002, 2009). ${ }^{8}$

The Confucian habit of the heart, i.e., the Confucian cultural disposition, forms a hierarchical authoritative structure with regard to status, generation, gender, and so on. For example, this is manifested in the unequal hierarchical authority structure between the clergy and the laity, between the elderly and the young, or between men and women in the religious community. This usually leads to the absence of a 'mutual and democratic communication structure' in the congregation, preventing the aforementioned latter groups from participating actively in the decision-making process in the congregational community.

In this regard, it is necessary to take into account the aspect of the 'Confucian disposition' of the Korean religious communities. Within the cultural context, the Confucian cultural disposition functions like a strong competitor against other religious habits. Therefore, in the context of Korean culture, religious life in congregational communities is invariably affected by Confucian cultural dispositions. Accordingly, this situation forms a unique religious environment where even contemporary Korean Christian communities remain ineffective in competing with other religions or congregations as well as challenging the (post)modern cultural circumstances.

In brief, when it comes to the understanding of religious competitions and innovations in the Korean cultural context, it is necessary to put a micro-level focus not only on those factors but also on the cultural dispositions which persistently affect them.

\section{Research Methodology—Five Case Studies}

This essay examines why some religions or congregations are more successful than others in the context of mutual competition, and whether they adopt any innovative solutions in order to be more competitive than others. For this, I have chosen to focus on major religious congregations in the Seoul downtown area since it appears to provide an ideal setting for research on such a topic. Of the different areas within Seoul's Metropolis, the downtown area has long been a hub, politico-economically and religiously, of the entire nation since the early part of the 20th century, providing an ideal battleground for religious movement and competition. There are diverse sectors of religious institutions thriving within the city, ranging from Protestant, Catholic, and Buddhist to traditional ethnic religions or newly risen religions. All have responded to and reflected upon the process of Korean modernization since the 19th century as well as contributed their fair share to the rise and fall of modern religions in Korea.

The period this research focuses methodologically on is from the 1990s to the present. Let me briefly explain its significance. First of all, the changing religious phenomena in this period call for a 'paradigm shift' in the ordinary sociology of religion. That is, the rise of such religious phenomena

8 Chae, relying on Bourdieu's concept of 'habitus,' regards Confucianism as a 'habitus' functioning like a 'habit of the heart' in Bellah's term. He argues that Confucian dispositions are functioning not only in Korean Protestant churches in Korea but also in Korean immigrant churches in the United States (Chae 2014). 
as 'believing without belonging' (Davie 1994), 'Spiritual But Not Religious (SBNR)' (Fuller 2001), and 'religious nones' is forcing a serious rethink of the ordinary sociology of religion, pushing it more firmly into the broader realm of culture and values (Woodhead 2017). This shift is particularly important in the context of East Asia with regard to the need for a new conceptualization of 'religion', 'religiosity', and 'secularity'. This study on YABs is aimed to reflect some of these changes.

Another significant point is associated with the demographic situation of the Seoul metropolis since the 1990s. Seoul rapidly expanded in line with the process of urbanization and industrialization for three decades since the 1960s, followed by a massive population influx into Seoul, resulting in an explosive population growth from 3.25 million in 1963 to 10.28 million in 1988. Protestants in Seoul also increased dramatically over the same period, from 0.23 million in 1966, 1.20 million in 1975 , 2.30 million in 1985, to 2.67 million in 1995. From the 1990s onwards, however, Seoul's population has consistently been stagnant at approximately 10 million. Similarly, the number of Protestants in Seoul has also been stagnant at the level of 2 million since the 1990s, and the similar stagnant situation is true of other religions. In this respect, migration pattern as a major demographic and ecological factor, which had a great impact on the religious population change in Seoul before the 1990s, does not appear to affect the decreasing trends of YABs in religious congregations in downtown Seoul at least after the 1990s. From a methodological point of view, such a demographic and ecological condition allows us to focus more efficiently on the subject of this study.

As stated above, this essay aims to explain why YABs leave their congregations and how their churches react to the growing frustration shared by YABs toward their religious faith. It goes on to further investigate whether it is feasible to seek and implement a series of innovative solutions that will prove to be effective in retaining and attracting YABs to their congregations of faith. As my findings illustrate, all five religious congregations take this situation seriously and monitor it closely as they try to evaluate and interpret this phenomenon in their own specific ways. Nonetheless, to date, efforts to retain and attract YABs have not been effective as they fail to address core issues facing many YABs. More precisely, it is likely that the falling number of YABs engaging in their congregational activities might be correlated to whether each congregation recognizes the ongoing religious changes as representing the situation of religious competition, as well as the extent to which the solution adopted by each congregation is actually 'innovative.'

To examine this point, I have conducted a series of in-depth interviews with five congregations. A total of five in-depth interviews were completed, the first one with 'Seoul Anglican Cathedral' on the 14 January 2016, and the last one with 'Cheondogyo Seoul Diocese' on the 3 August of the same year (see Table 1). In some cases, after the formal focus group interview, it was necessary to follow up with additional or supplementary questions via telephone or email.

In general, each interview comprises two parts. Part one is designed to grasp interviewees' demographic and religious or spiritual characteristics through structured interviews or questionnaires. Part two is designed to collect information on interviewees' feelings, thoughts and solutions to the declining religious participation of YABs through semi-structured questionnaires. Following the Focus Group Interview (FGI) methodology, one of the main qualitative research methods used for interpreting inherent motivations, reasons, and structures in depth (Krueger and Casey 2008), three respondents were chosen from each congregation to answer the survey: one pastor representing the leadership of the YABs group; and two young adult group members. To protect privacy, respondents' names in each congregation have been anonymized with $\mathrm{A}, \mathrm{B}$, and $\mathrm{C}$ as shown in Table 1 below. With the exception of Cheondogyo Seoul Diocese Congregation, I have allocated two hours to each interview. Additionally, the nationwide survey data set 'Korean General Social Survey (KGSS)' and 'Statistics Korea' have been utilized to determine the prospect of religious patterns and status as shown in Figures 1 and 2. 
Table 1. Overview of Focus Group Interviews (FGIs) on Five Congregations. (YABs = young adult believers.)

\begin{tabular}{|c|c|c|c|c|c|}
\hline & $\begin{array}{c}\text { Youngnak } \\
\text { Presbyterian Church }\end{array}$ & $\begin{array}{c}\text { Seoul } \\
\text { Anglican Cathedral }\end{array}$ & $\begin{array}{c}\text { Myeongdong } \\
\text { Catholic Cathedral }\end{array}$ & $\begin{array}{c}\text { Bulkwang } \\
\text { Buddhist Temple }\end{array}$ & $\begin{array}{c}\text { Cheondogyo Seoul } \\
\text { Diocese Congregation }\end{array}$ \\
\hline Origin & $\begin{array}{l}\text { Established in } 1945 \text { by then } \\
\text { Rev. Kyung Chik Han }\end{array}$ & $\begin{array}{c}\text { Established in } 1891 \text { under } \\
\text { the name of 'The Church } \\
\text { of Advent' }\end{array}$ & $\begin{array}{l}\text { Built in 1898, the } \\
\text { Cathedral Church for the } \\
\text { Archdiocese of Seoul }\end{array}$ & $\begin{array}{l}\text { Established in } 1974 \text { in } \\
\text { downtown Seoul, moved to } \\
\text { Gangnam district in } 1982\end{array}$ & $\begin{array}{l}\text { Started in } 1860 \text { with Donghak } \\
\text { (Eastern Learning) }\end{array}$ \\
\hline Congregation Size & Approx. 60,000; YABs: 1000 & Approx. 1500; YABs: 50 & $\begin{array}{l}\text { Approx. } 19,000 \text { (as of } \\
\text { 2013); YABs: } 100\end{array}$ & $\begin{array}{c}\text { Approx. 12,000 (enrolled); } \\
6000 \text { (regular attendees); } \\
600-700 \text { (weekly attendees); } \\
\text { YABs: } 80\end{array}$ & $\begin{array}{c}\text { 'Unknown' or 100,000 } \\
\text { nationwide; YABs: approx. } \\
1000 \text { nationwide (aged 20-45) }\end{array}$ \\
\hline Religious and ideological value orientations & $\begin{array}{l}\text { Moderate conservative } \\
\text { evangelical Protestantism }\end{array}$ & $\begin{array}{c}\text { Moderate liberal } \\
\text { and progressive } \\
\text { evangelical Protestantism }\end{array}$ & $\begin{array}{c}\text { Moderate liberal } \\
\text { and progressive } \\
\text { evangelical Catholicism }\end{array}$ & $\begin{array}{l}\text { Moderate evangelical } \\
\text { Buddhism, but liberal in } \\
\text { missionary works }\end{array}$ & $\begin{array}{l}\text { Passive moderate } \\
\text { conservative }\end{array}$ \\
\hline \multirow[b]{2}{*}{ Time and Place } & $\begin{array}{c}\text { A, in charge of YABs } \\
\text { Group/s; B, Former } \\
\text { President of YABs Group/C, } \\
\text { Vice-President of } \\
\text { YABs Group }\end{array}$ & $\begin{array}{l}\text { A, in charge of YABs } \\
\text { Group; B, President of } \\
\text { YABs Group; C, } \\
\text { Vice-President of } \\
\text { YABs Group }\end{array}$ & $\begin{array}{l}\text { A, Director of Youth } \\
\text { Ministry; Seoul } \\
\text { Archdiocese; B, Church } \\
\text { Youth Group (Middle and } \\
\text { High School); C, in } \\
\text { charge of YABs Group }\end{array}$ & $\begin{array}{l}\text { A, in charge of YABs } \\
\text { Group; B, President of } \\
\text { Temple YABs Group }\end{array}$ & $\begin{array}{l}\text { A, General Secretary of } \\
\text { Central Headquarters of } \\
\text { Youth Group }\end{array}$ \\
\hline & $\begin{array}{l}\text { Prayer Center on } \\
21 \text { January } 2016\end{array}$ & $\begin{array}{l}\text { Priest's office on } \\
\text { 14 January } 2016\end{array}$ & $\begin{array}{c}\text { MDCC Archdiocese } \\
\text { Building on } 20 \text { July } 2016\end{array}$ & $\begin{array}{l}\text { Priest's office on } \\
9 \text { April } 2016\end{array}$ & $\begin{array}{c}\text { Cheondogyo Sueun BD on } \\
3 \text { August } 2016\end{array}$ \\
\hline
\end{tabular}


Key topics discussed through FGI with each congregation are as follows:

- Value orientations of Ministry: conservative, progressive, liberal, evangelical.

- $\quad$ Responses to current decline of YABs population.

- $\quad$ Current stances on faith: 'Spiritual But Not Religious (SBNR)' or 'Believing Without Belonging $(\mathrm{BWB})^{\prime}$.

- Recognition of (Confucian) cultural disposition.

- Recognition of religious competition and innovation.

\section{Data Analysis and Findings}

The data analyses consist of the above-mentioned four key topics regarding congregations' responses to the current religious situation and their recognition of competitions and innovations. Of these four topics, the first three are reviewed together in the first part, and the last is reviewed in the second part. Thus, rather than reviewing these topics horizontally on a one-by-one basis according to congregation, we examine the five organizations consistent with the order the four key topics are placed in. By doing so, we can analyze the activities of comparative advantage in terms of religious competition and innovation performed by each congregation and draw implications from these comparisons.

Before examining the four topics, we need to briefly discuss the congregation's religious and ideological value orientations towards the external environment and circumstances. Phenomenological sociology pays particular attention to a 'perspective system', reflecting the value orientation of a certain group or class as it forms a collective way of seeing the world. Following Schutz's socio-phenomenological insight, Geertz defines 'perspective' as 'a mode of seeing, in that extended sense of "see" in which it means "discern," "apprehend," "understand," or "grasp." It is a particular way of looking at life, and a particular manner of construing the world (Geertz 1993, p. 110). Each perspective has its own logic of seeing the world, such as the common-sensical perspective, the scientific perspective, and aesthetic perspective, and Geertz emphasizes that the religious perspective is differentiated from the other three perspectives in terms of which men construe the world (ibid., p. 112). Accordingly, a certain congregation's value orientation has a bearing on its perspective as it affects the way it construes the external world or situations. This, in turn, shapes the way in which the congregation competes with other congregations or religions.

So, following the typical category framework for the 'value orientations,' we can characterize the patterns of the value orientation of the five congregations as 'conservative,' 'progressive,' 'liberal,' and/or 'evangelical.' Of course, the value orientation of a religious congregation has a distinctive characteristic according to time and culture, to which the congregation belongs. So, the logic of the categorization of the four value orientations reflects the cultural and historical backgrounds that affected the development of Korean Protestantism, Catholicism, Buddhism, and ethnic religions including Cheondogyo since the 19th century. ${ }^{9}$ First of all, the religious and ideological value orientation of Korean Protestantism was influenced by both the 'conservative' North American Presbyterianism and the 'progressive' Canadian Presbyterianism from the beginning. More than a century later, the structure of these two value orientations in Korean Protestantism has remained unchanged very much. The case of Korean Catholic Church, influenced by the Foreign Missions Society of Paris, is different. Like other foreign religions, its initial value orientation was 'innovative' along with the modernization process of Korean society but remained 'conservative' for a while in the political arena. Since the Vatican Council II, the Korean Catholic Church has held ideologically 'liberal' and 'progressive', but, on the other hand, it has been 'evangelical' in a doctrinal sense, as evidenced by the positions against the ordination of women priests and abortion. These pluralistic value orientations of 'liberal', 'progressive', 
and 'evangelical' are true of Korean Anglican Church. However, the Korean Anglican Church appears to be less doctrinal than the Korean Catholic Church. Korean Buddhism, as a traditional religion, has long been 'conservative' and 'evangelical' in socio-political and doctrinal terms, but seems to have recently become 'liberal' in the so-called postmodern relativistic cultural milieu. Lastly, since its founding, Chondogyo has held 'innovative dynamics' for a long time in socio-political terms, similar to most ethnic religions that emerged in the late 19th century. However, since then, with the dramatic decline in membership in the 1970s, it has been consistently 'passive' and 'conservative'.

On the basis of the understanding of these cultural and historical contexts, we can view congregations' stances and responses to religious change, specifically the ongoing decline of the YABs, and furthermore examine whether they apply any competitive and innovative solutions to it. As we will see in what follows, this assumption seems to be, in fact, largely consistent with the cases of the five congregations.

First, let us take a look at Youngnak Presbyterian Church ('YPC' hereafter). Established in 1945 by the then Rev. Kyung Chik Han with two dozen refugees from communist Soviet-occupied North Korea, YPC is one of the mega churches in Korea as well as one of the mega Presbyterian churches worldwide. Its charismatic founder Rev. Han won the Templeton prize in 1992 for his influential and respectful Christian life and leadership both at home and abroad. YPC has remained actively involved in its evangelical work to promote social welfare with the mission of serving the underprivileged sector of our society. Furthermore, the church has continued with its special mission to provide support to North Korean refugees. The background to its origin and missionary inclination evidently shows YPC's value orientation can be defined as 'moderately conservative evangelical Protestantism.'

Next is the Seoul Anglican Cathedral ('SAC' hereafter). It was first founded in 1891 and the Cathedral was built in 1926 under the guidance of Bishop John Corfe. An extension was made in 1996 according to its original blueprint. The cathedral's first Korean bishop was consecrated in 1965 as Korea became an independent diocese. SAC helped to usher in the era of the democratization movement as the first national conference for the Korean democratization movement was held here in 1987. Until this day SAC has been deeply involved in working with community welfare ministries, the center for homeless service and shelter, the study center for underprivileged children, Food Bank, and many more. After reviewing its political inclination and deep involvement in social missionary works, SAC's value orientation can be assessed as representing 'moderate liberal and progressive evangelical Protestantism.'

The value orientation of SAC as 'moderate liberal and progressive evangelical' is shared by the Myeong Dong Catholic Cathedral ('MDCC' hereafter), the third religious congregation to be reviewed. Built in 1898, MDCC is both the Cathedral Church for the Archdiocese of Seoul and Myeong Dong Catholic Church. MDCC has become a symbol for the existence of catholic churches in Korea. In 1942 the first Korean parish priest, Fr. Rhee Ki-Jun, was appointed as pastor of Myeong Dong, and the first Korean Bishop Rho Ki-Nam was promoted to the rank of episcopate. Throughout the 1970s and 1980s, MDCC served as the headquarters for the democratic movement in Korea and has played a vital role in the expansion of human rights in the country.

In contrast, both Bulkwang Buddhist Temple ('BBT' hereafter) and Cheondogyo Seoul Diocese ('CSD' hereafter) share value orientations that can be defined as 'conservative.' In the case of BBT, it was first established in Seoul's downtown district of Jongno-gu in 1974. A few years later in 1982, the congregation moved to the newly-developed district of Songpa-gu located in the southern part of Seoul. Its basic orientation clearly represents the 'conservative evangelical' elements of Buddhism. But surprisingly, an interview of the temple's missionary activities reveals a considerable level of liberal orientation. This peculiar quality reflects both active and innovative missionary works carried out by BBT in its effort to adapt to its newly migrated region. However, it soon became evident that its efforts were not enough to prevent the population of YABs from falling.

The last religious congregation to be reviewed is the Cheondogyo Seoul Diocese (CSD). Initially it started as an ethnic religion in 1860 called Donghak, or Eastern Learning, founded by the Confucian 
scholar Choe Je-U. It spearheaded the religious movement toward social participation during the turn of the 20th century and brought about many socio-political changes and movements like the 'Donghak Peasant Revolution' in 1894. At its peak, its congregation was believed to have reached three million, but the number has dramatically declined since the 1970s. Presently, its total number of followers make up less than 100,000 nationwide. Such a dramatic drop in its followers indicates that CSD has been less active and effective in competing with other religious congregations, implying it has made no attempt to adopt any innovative changes to cope with the rapidly changing postmodern world. Therefore, it is safe to say CSD falls in the category of 'passive moderate and conservative' orientation, as can be seen in the following research.

\subsection{Responses to the Decline of Young Adult Believers Population in the Changing Religious Environment}

The number of YABs in the five congregations in the downtown Seoul area has continued to decline throughout the past two to three decades. This clearly reflects a continuous declining trend, shown in Figure 2 above. The downward trend of the YABs population definitely poses a challenge to the five religious congregations. As mentioned earlier, this inevitably forces one to examine their status from a micro perspective. The following outlines the key points to be reviewed: What are the factors religious congregations consider as the reasons for the growing number of YABs deserting their faith?; How do they respond to changing religious phenomena, including 'SBNR' and 'Believing without Belonging'?; And how do religious congregations view cultural disposition based on traditional Confucianism, which usually renders congregations ineffective when competing with others and changing religious realities?

Let us observe these issues at hand one by one in detail. First, the number of YABs at YPC had been in a gradual 'upward trend' during the last three decades from the 1980s to 2000s. In contrast, in the years that followed, this trend had reversed and shifted downward. The total number of both college students as well as non-college students started to decline since the 2000s and 1990s, respectively (See Table 2). This subtle but clear sign of 'downward trend' is expected to continue. ${ }^{10}$

Table 2. Trend of YABs at Youngnak Presbyterian Church.

\begin{tabular}{ccccc}
\hline & $\mathbf{1 9 8 0}$ & $\mathbf{1 9 9 0}$ & $\mathbf{2 0 0 0}$ & $\mathbf{2 0 1 5}$ \\
\hline No. of college students. & 330 & 390 & 470 & $470 \Rightarrow 450$ \\
No. of non-college students. & 630 & 650 & 600 & 520 \\
\hline
\end{tabular}

A, who leads the YABs group, is pessimistic when talking about the future of YABs. He believes the relationship between church and young adults will likely be weakened in the future. He asserts even YABs who have been devoted followers of the faith and church will face hardships that may undermine the importance with which they regard their church-centered religious lives. In this respect, A is alarmed at what the future may hold for his religious community.

A especially points to a 'mismatch of faith language existing between generations' where congregation leaders still use old-fashioned manners of speech that can result in alienating YABs. He explains why he thinks this happens in the following:

The language we use to describe our faith experiences that we had received from the past generation no longer fits the language of our next generation. It is not simply about how the language has changed but the next generation needs an upgraded language to express their own experiences. And for that language becomes the language of the community.

He continues on to say:

10 At its winter camp for YABs held in January of 2016, the attendance rate decreased by nearly $30 \%$ when compared to the previous year. 
(So,) it is because they [YABs] had been using the language of the older generation. They were never given a chance to express their feelings using the language they were familiar with. Because they had trouble relating to the language they have heard and learned from their seniors, the language was not enough to help them interpret the meaning of their lives. (... ) So I think the youths need their own language of faith that can actually help them express themselves more accurately.

Of course, this mismatch of faith language between generations does not merely reflect the generation gap in the general sense. Rather, as mentioned earlier, it has to do with the aspect of 'cultural disposition' of Korean society which has been closely identified with the Confucian habit of the heart. As noted by Jeon and Kinnaman on the detrimental effect of authoritarianism in the religious community (Kinnaman 2011; Jeon 2017), it reflects a stubborn authoritarian atmosphere with the 'seniority rule' applied to it. The same holds true for the other four congregations. A seniority-based culture is indispensably related to that of hierarchical order, which leads to an absence of a 'mutual and democratic communication structure,' and prevents YABs from actively participating in the congregation's decision-making process.

In fact, this aspect seems to be perceived more clearly by foreigners than by Koreans. A German Protestant priest, Rev. Malte Rhinow, who has lived in Korea for 25 years, keenly observes that Confucianism has had a negative impact on the Korean church community. He particularly points out its hierarchical influences upon the cultural and linguistic dimensions of the Korean church community. According to the reverend, it filters into the honorific-humble language system of the priests' sermons and the Korean biblical texts, and even into the logic of the altar decoration (Rhinow 2017, pp. 77-82, 155-59).

However, despite the fact that the faith-language mismatch existing between generations reflects Confucian cultural disposition, which generates the undemocratic communication structure within the congregation, leaders of YABs do not regard this reality to be serious. C, vice-president of the YABs group, thinks that, like other mega churches, this is an area that may require his church leadership to organize an authoritative group to effectively manage its parishioners as well as resources. And $\mathbf{B}$, former president of the YABs group, also emphasizes that the YPC leadership is the one given to spiritually submissive leaders and therefore she sees no urgency to address the generational conflicts in a serious manner.

This perspective seems related to the 'moderate conservative' value orientation of YPC towards the changing environment. They recognize somewhat the seriousness of changes occurring throughout religious communities described as 'Spiritual But Not Religious' or 'Believing without Belonging,' but treat them as being 'inauthentic.' A regards them as a type of 'infant faith' which potentially can lead young believers to nurture an 'egoistic and atomistic self' and end up with an 'undesirable and dangerous faith.'

In comparison, the SAC has a different attitude towards the changing religious environment. Most importantly, the number of YABs recorded an upward trend during the 2010s (see Table 3), in contrast to a drastic 'downward trend' of YABs during the last two decades of the 1990s to 2000s. Unlike all of the other four congregations, however, it has shown a gradual sign of 'upward trend' since the period spanning from 2010 (See Table 3). ${ }^{11}$

11 Winter camp attendance in 2016 recorded a slight increase. 
Table 3. YABs at Seoul Anglican Cathedral.

\begin{tabular}{ccccccc}
\hline & $\mathbf{2 0 1 0}$ & $\mathbf{2 0 1 1}$ & $\mathbf{2 0 1 2}$ & $\mathbf{2 0 1 3}$ & $\mathbf{2 0 1 4}$ & $\mathbf{2 0 1 5}$ \\
\hline Confirmed & $16 / 28$ & $36 / 52$ & $12 / 16$ & $28 / 47$ & $40 / 56$ & $36 / 59$ \\
Baptized & $12 / 22$ & $12 / 22$ & $14 / 19$ & $17 / 24$ & $18 / 24$ & $16 / 38$ \\
Total & $28 / 50$ & $48 / 74$ & $26 / 35$ & $45 / 71$ & $58 / 80$ & $52 / 97$ \\
\hline
\end{tabular}

It is worth noticing that though small in numbers, traces of young adult believer membership increasing at SAC despite its liberal and progressive nature have been detected throughout the past ten-year period. In fact, it has been axiomatic for decades that progressive religion has stagnated while evangelical religion has grown. Indeed, throughout the 1980s and 1990s, most of the liberal and progressive denominations such as the Presbyterian Church and the United Church of Christ throughout North America have shown a sharp decline in terms of their membership (Kim 2005; Martin 2001). A similar phenomenon can also be seen in Korea. According to analytical studies conducted by Park and Jung (Park and Jung 2006, pp. 208-12), the growth of Protestant churches in Korea throughout the 1980s and 90s was the result of increased conservative congregations rather than congregations of liberal and progressive nature with reformative and social participatory characteristics.

As seen below, such an anomaly within SAC is likely to be related to the unusual efforts it has made to retain YABs. Unlike the four religious congregations, SAC is one of the few institutions that has concentrated its efforts on attracting YABs, updating religious teachings and hosting innovative events like 'Theological Chatters' where YABs are encouraged to speak openly about spiritual as well as personal matters instead of focusing solely on scriptural studies. This topic needs to be further discussed in detail later.

The active attitude adopted by SAC is well reflected in $\mathbf{A}^{\prime}$ s view on the status of religious institutions as being 'Spiritual But Not Religious' and 'Believing without Belonging.' He expresses serious concern about the current situation but puts more emphasis on the positive elements. He states that

the Anglican Church echoes very well the on-going pattern of SBNR, since in its nature, it goes well not with the doctrinal but with the spiritual, even though it is, in its formality, 'religious' with a liturgical basis.

However, he treats them as being 'procedural authentic.'

However, I do not think this "SBNR" trend is a timely solution. This is because focusing solely on the "spiritual" aspect is irresponsible. I think that everything should be put in a bowl. And I think that the Anglican Church should be that bowl. Not with the doctrine but by having the liturgical service as a loose structure, we can be the bowl.

A believes optimistic and positive elements making up SAC can turn the ongoing dire situation into opportunity. In this regard, he argues that the Anglican church exhibits characteristics very appropriate to the era defined as 'spiritual turn' (Heelas and Woodhead 2005; Holmes 2007) and asserts his belief by stating "I think, with personal conviction, that the Anglican church has long been waiting for the 21st century and believe with conviction that we are representative of the 21st century church and theology."

With regard to the Confucian cultural disposition, all of the interviewees from the Anglican congregation remained strongly critical of it. They all point to its strong authoritarian and un-democratic structural atmosphere, which equally apply to both lay person and clergy. They all agree that Confucian cultural habits such as the 'seniority rule' demonstrate how the congregation has hardly taken a step away from its traditional authoritarian ways even though it values the parliamentary system. For example, both leaders of the YABs group point out the fact that their church has no place for young adult members in the committee. C, vice-president of the YABs group, makes the following point:

"We should be able to voice our opinion by having rights to become committee members.... we need young adult members and female members as well. Furthermore, we request an improved implementation process for decisions made by the committee." 
They unanimously suggest that, in order for the church to uphold democratic values, it should make room for young adult members to participate in the committee using the quota system to guarantee fair representation of YABs. As the following findings will show, traces of an active attitude on the part of SAC appear to be distinctive when compared to the conservative values the other four congregations are adhering to.

The number of YABs belonging to the congregation of MDCC has declined sharply since the mid-2000s (See Tables 4 and 5). This, in turn, reflects the rapid decline in Korean Catholicism during the same period. According to the 'Population and Housing Census of 2015,' the Catholic population, which was 5.01 million in 2005, dropped significantly to 3.89 million in 2015. This is a dramatic change compared to the upward growing trend Catholic congregations have recorded over the previous two decades. Unlike the Korean Protestant church, the Korean Catholic population increased significantly over the span of two decades, from the 1990s to 2000s. Statistics show that during this period, the population increased significantly from 2.88 million to 5.01 million, while that of Protestant churches decreased slightly from 8.50 million to 8.44 million. Thus, the decline of Catholic YABs since the mid-2000s is a phenomenon that reflects the dramatic decline of Korean Catholicism in general.

Table 4. YABs at Myeong Dong Catholic Church ${ }^{12}$.

\begin{tabular}{ccc}
\hline $\mathbf{1 9 9 0}$ & $\mathbf{2 0 0 0}$ & $\mathbf{2 0 1 6}$ \\
\hline 140 & 180 & 100 \\
\hline
\end{tabular}

Table 5. YABs at Seoul Archdiocese (aged 20-29).

\begin{tabular}{cccc}
\hline $\mathbf{1 9 9 6}$ & $\mathbf{2 0 0 0}$ & $\mathbf{2 0 0 7}$ & $\mathbf{2 0 1 5}$ \\
\hline 215,000 & 261,000 & 220,000 & 174,000 \\
\hline
\end{tabular}

C, leader of the YABs group at MDCC, sees this downward trend as being caused by external factors. He says:

Young people, due to social structural problems, are not able to achieve self-realization, thus making it hard for them to focus on religious activities. ( ... ) To put it more concisely, today's youths do not have time to come to church even if they want to because they have no time to spare. This is probably the main reason for the growing number of youths giving up their religious engagement.

In a similar vein, $\mathbf{A}$, the director of the Youth Ministry Department at Seoul Archdiocese, highlights two social factors: the Korean education system and family composition, which has gone through major changes over the last few decades. First, he points out, the education system, which is excessively focused on college entrance and whose extreme level of competitiveness is visible throughout the society, greatly impact the YABs. Secondly, the rising number of nuclear families or smaller-sized households, including the new generation of single-parent families, has also affected young adults' behavior. In particular, B, the leader of the middle and high school youth group, highlights the impact a single-parent family has on YABs:

Youths raised in single-parent households develop a survival mechanism to protect their basic livelihood and they question what is most important to themselves and their lives. The answers they reach are more about competition and survival rather than love, service, or their passion or dreams. ( ... ) Sadly, findings show the reasons for young people going to

12 At Myeong Dong Catholic Cathedral, there are a large number of YABs who attend Sunday Mass but are not registered with the Church. 
church is not for their salvation but to simply find rest and encouragement. This is the sad reality facing the religious community. ( ... ) There is nothing better than findings ways for the church to take care of these young people but it will definitely prove to be difficult.

The MDCC remains highly vigilant with regards to the declining number of YABs and its implication. Nevertheless, the MDCC seems to regard the reality as less serious and is less likely to take on an active response. All three priests seem to believe that it is natural for young adults to leave their faith for their own personal reasons while others may flow back to find their faith. Similarly, just as every flow has its ebb, the flow of faith for young religious believers comes and goes.

This changing perspective is reflected in the ways transforming religious phenomena are described as 'SBNR' or 'Belonging without Belonging.' They consider them circumspectly but regard them only as epiphenomena belonging to the religion or religiosity. It is because they view religion (or religiosity) and spirituality as being inseparable, an individual faith separated from the church community is not desirable.

This passive and conservative view of religious changes also appears in the lasting influence of Confucian cultural disposition within the church community. When asked about the Confucian cultural disposition that requires church leadership to abide by the 'seniority rule' or 'elders-first custom' and which results in producing a non-democratic environment, A replies that it is typical Korean cultural practice to simply follow the old ways, just as the old saying of 'when in Rome, do as the Romans do' suggests. When church leadership including priests maintain a perspective that is outdated and passive, it will most likely prevent them from recognizing Confucian cultural disposition as the reason behind an internal structure that obstructs democratic communication and decision making within the church community. Furthermore, they will be unable to see that Confucian cultural disposition causes YABs to remain inactive in participation and alienated from key activities. This is in contrast with the transformation SAC is undergoing, as we have already observed in the previous chapter.

Now, let us examine the non-Christian congregations of BBT and CSD. Both religious congregations show that the number of their YABs is declining faster than that of Christian congregations. Specifically, the number of YABs belonging to BBT has rapidly decreased since the early years of the 2000s (See Table 6).

Table 6. YABs at Bulkwang Buddhist Temple.

\begin{tabular}{ccc}
\hline 1980-90 & $\mathbf{2 0 0 3}$ & $\mathbf{2 0 1 5}$ \\
\hline Approx. 100 & 136 & 80 \\
\hline
\end{tabular}

A, who serves as the leader of YABs group, believes that this downward pattern is not a problem inherent in the temple itself but rather it is a byproduct of the socio-economic and political situation of the society. The same is true of $\mathbf{B}$, the president of the YABs group. $\mathbf{B}$ particularly points to the unemployment trend since the 2000s, which contributed to the declining pattern of YABs belonging to the Temple. He says:

They [YABs] keep themselves extremely busy preparing for various sets of qualification exams that they literally have no time to spend on YABs' activities or attend Buddhist services. As a leader of the YABs group, I try to come up with some attractive and appealing programs but nothing brilliant comes to mind.

Both leaders appear to be somewhat concerned with the declining number of YABs since the 2000s and what this phenomenon implies, yet they seem to approach the situation with a certain level of leniency, which might prevent them from realizing the need to take proactive measures and responses. This attitude is well reflected in describing major concerns surrounding BBT, as noted by A:

( ... ) to be honest, I think temple administrators are actually more interested in and put priority on other issues and YABs are not their main concern. It has always been this way, 
don't you think so? This implies, in general, the Temple's policies don't necessarily put guidance and support for YABs at the top of their priority list.

Meanwhile, A firmly regards new spiritual practices like 'SBNR' or 'Belonging without Belonging' as a 'vulnerable form of religious life' generated in the Western postmodern culture. He makes a distinction between Buddhist spiritual practices and Western spiritual practice as defined by 'SBNR' or 'Belonging without Belonging.' He emphasizes that although Buddhism is related to spiritual practice, its practice is inseparable from the communal life. And he acknowledges how important the dimension of communal life guided by doctrine and asceticism has been in enabling Buddhism to sustain its place for nearly 2600 years since its birth. He further points to the vulnerability of spiritual practice:

This [turning to 'spirituality'] seems to be an appealing element in this postmodern world. That is because new religious movements or something similar to spiritual revolutions that originate from personal experience attract followers. But, (...), that might not be sustainable and induce undesirable psychological or mental conditions. (... ) This is why I believe there is a certain gap between the Buddhism practiced in Europe, which solely emphasizes 'spiritual practice,' and the traditional Buddhism found in Korea.

With regard to the Confucian disposition, both leaders acknowledge its significant influence on the congregational community in the sense that it may generate an undemocratic and authoritative atmosphere. Therefore, they say their decision-making processes in the congregation try to reach a middle ground wherein top-down and bottom-up conflicts are resolved through compromise. For instance, when preparing for a ceremony to celebrate Buddha's birthday, all Temple members normally follow the rules of guidance set by the executive team, who takes charge of preparing for the event. But for decisions relating to other events like summer training camp, the YABs group takes full responsibility for the decision making. A argues that, in this respect, their Temple leadership has adopted a wise solution that finds a middle ground that enables compromise to be reached between authoritative (dogmatic) and democratic forces within the Temple administration.

Nevertheless, until the present, the YABs group members have not been entitled to participate in the Temple committee. Surprisingly, the two leaders seem the least uncomfortable about this rule and show no interest in giving this problem a critical look. Therefore, it is safe to assume the BBT community still sees no need to establish a democratic structure through which YABs are encouraged to participate in the congregational decision-making process.

Now, let us turn to the situation facing YABs belonging to the CSD congregation, as their status appears to be most critical when compared to the rest of the four congregations (see Table 7). ${ }^{13}$ The following statistics table shows a dramatic decline of YABs membership since the period after the 1970s and 1980s.

Table 7. YABs at Cheondogyo Seongnam Diocese, Gyeonggi-Do Province.

\begin{tabular}{ccc}
\hline 1970-80s & 1990-2000s & 2016 \\
\hline Approx. 100 & $20-30$ & 5 \\
\hline
\end{tabular}

A, who currently serves as the General Secretary to Central Headquarters of the CSD YABs group, answers the question on the steep drop of YABs membership and reasons for this phenomenon in the following way:

Inside the Cheondogyo, one of the major concerns is that young adults do not know why they need religion in their lives. ( . . ) why religion should always remain as part of their

13 CSD did not provide their YAB statistics, but instead provided YAB statistics for the Seongnam Diocese of Gyeonggi-do Province. These statistics are likely to reflect the overall situation of YAB congregations belonging to Cheondogyo. 
lives. Life is already busy enough for YABs, and what's more, our Cheondogyo scripture had been written in the Joseon dynasty, so it is difficult (to understand). (... ) the text is not aligned horizontally but vertically and though I think it has merits it is not enough to enable its followers to find joy and be interesting enough to draw interest from the young people of today.

This situation clearly illustrates CSD's 'passive moderate conservative' orientation as discussed earlier. A, who is in her late twenties, defines this orientation as extremely conservative. She understands that her religion, Cheondogyo, does not have qualities attractive enough to appeal to the younger generation of believers. Her response to the question of whether there had been any efforts made on the congregational level to make changes is as follows:

Yes. I heard about the efforts undertaken to reshape our organization. These included scripture made for children and/or scripture made easy for young adults to understand. Church administrators deliberated on the possibility and they actually experimented with the ideas but they are no longer accessible. There have been similar small attempts but none led (even until now) to a larger tidal change.

This passive conservative atmosphere seems to have hovered over the entire congregation of Cheondogyo since the 1970s. This downfall is in dramatic contrast to its influential period when the Cheondogyo congregation led many socio-political changes and movements and, by the mid-20th century, its total membership had once reached three million.

Most of all, the biggest obstacle facing CSD when dealing with the YABs issue is that the congregation has failed to take any concrete steps to analyze the current status and adopt alternative measures to overcome its past weaknesses and prepare for both today and the future. A responds to the question on whether any attempts or actions have been taken by YABs members to make internal changes in the following manner:

Consensus within the youth assembly is pessimistic and many believe there is nothing for them to do anymore. Some say they have already reached their limits trying to make a difference. Likewise senior members also show grave concern. But I feel it will be quite a challenge for both parties to reach an agreement. Within the senior circle ( ... ), they worry about what direction they should be heading and how they should continue on with the legacy left by their founder.

In many respects, CSD appears to be in the midst of a long-term recession. In particular, the situation YABs presently find themselves in as future members of the congregational leadership looks quite gloomy and daunting at the same time. This is not surprising at all when considering that present and future prospects for YABs belonging to the CSD congregation are hard to discern, as mentioned earlier. It is not too difficult to sympathize with YABs at CSD who feel neither interested nor want to engage in discussion on the subject of bringing changes to their church as they continue to remain faithful to their religious disposition as 'SBNR' or 'Believing without Belonging.' As a matter of fact, sadly, the congregational leadership at CSD, including the person interviewed, $\mathbf{A}$, remained clueless to and not the least interested in dealing with the unfolding series of changes in demand. Naturally, they were not competent enough to respond to calls to tackle problems facing the present-day congregation. Similar problems evolve when dealing with the issue involving Confucian cultural disposition.

\subsection{Recognition of Religious Competition and Innovation}

By examining the series of responses given by different religious congregations, it is possible to understand where they stand when dealing with the evolving changes and their current status. To elaborate, the FGI survey has shown how serious each religious congregation recognizes their current situation to be and what sort of attitude each congregation presents toward the demand 
for changes. The following part of the essay will observe and examine in detail the solutions each congregation has, or the plans they will adopt in order to render their organizations competitive and innovative. Therefore, the basic framework of this survey is designed to illustrate how each congregation perceives the changing religious situation, as one of many competitors engaged in a race to attain sustainability for future generations, and their plans to develop and implement creative and innovative measures to stay competitive.

Let us first discuss the case involving YPC. The survey shows YPC's conservative orientation towards the changing religious situation provides a different take on how it can be interpreted as leading to religious competition. Accordingly, in this respect, the church is less likely to engage their congregational leadership to actively seek for creative and innovative programs. Nevertheless, $\mathbf{A}$, who is in charge of the YABs, saw how serious the general gap that exists between older and younger congregants over faith language can be. He decided to try a new experiment. He recently implemented an experiment called 'Sketchbook' to help YABs recover and retain their language of faith. ${ }^{14}$

The Sketchbook program was introduced to tackle the language mismatch between older and younger generations when learning about faith, as well as to attract YABs to become congregational members. They were encouraged to participate in discussion sessions. A has the following to say on the matter:

[During the Sketchbook program], I did the basic talking. People who wanted to take part came in groups of 6-7. For 3 weeks, every Thursday, we spent $3-4 \mathrm{~h}$ talking about and listening to one's personal life stories which were not confined to matters concerning one's worries, prayer requests, or questions on faith. Because it was done in small groups, we were able to understand and empathize with one another. However, most of the members who attended the meeting came to talk about their lives and get counseling.

A emphasizes the importance of interactive skills when teaching religious faith to a young congregation. He asserts teaching faith no longer should be based on a unilateral process where young people are taught to 'simply believe.' Instead he highlights the need for interactive communication when teaching and learning about faith. He believes faith should be taught through conversation. The reasons for growing one's faith should be well explained and this process can transpire to become grounds for self-testimony. Learning faith through communicative engagement will enable young individuals to search for reasons to believe and become active members in their religious community far more effectively.

In this respect, the Sketchbook program may potentially be recognized as an innovative approach that will provide informal meetings for the YABs congregational group where they openly and freely discuss both personal and religious matters. Apart from its innovative quality, the Sketchbook program has its limitations as it does not attempt to delve into the detrimental effects of Confucian cultural disposition, which is known to create an undemocratic communication structure within the religious congregation. This is quite different from the innovative steps taken by the SAC.

The overall assessment shows SAC to be far more active and innovative than other religious congregations. SAC does not appear to share the view that the changing religious situation can be defined as religious competition. Instead, the church strongly believes its congregational community could turn the situation into an opportunity by and through which it is prepared to take on an important religious role in the 21st century. Despite the gloomy outlook on sustaining its YABs population, SAC remains optimistic and confident in its ability to turn this critical period into valuable opportunity. A has faith when he confesses "I with personal conviction believe that the Anglican Church has long been waiting for the 21st century to open and we are ready to become the church and theology representing the 21st century."

14 For the basic idea behind Sketchbook, A was inspired by a TV music program called 'Yoo Hee Yul's Sketchbook.' 
As mentioned earlier, in 2016, SAC's YABs group began a new innovative experiment called 'Theological Chatter' at a dessert cafe near the Church. It is open to everyone regardless of whether one is religious, irreligious or atheist, and anyone interested can join the group to contribute to an open and free conversation on any subject matter. ${ }^{15}$ Currently, the YABs group known as 'Brothers of Peace' host the event once every month. They are implicitly hoping the YAB membership grows large enough to account for $10 \%$ of the entire population of regular church attendants, i.e., 100-150 members in total.

A stresses the importance of attracting young new members to the religious community by outlining what will happen. He knows as many lifetime congregational members age, they become less and less active in their religious community. Also, through today's so-called postmodern culture that influences our lives, the religious community tends to increasingly lose its vitality. In order for the religious congregation to remain vibrant, it must persistently search for ways to attract new and YABs. He therefore understands that Theological Chatter represents innovation developed through creative and innovative methods. He seems very positive and has ambitious expectations for the future, as described below:

Firstly, I want to make it a guilt-free zone, where they [newcomers] can ask questions (not confined to religious matters) even in the presence of a priest.( ... ) Secondly I want them to be able to express with their own language how they feel about the church and be able to interactively communicate. I want to help them realize that the language of the church speaks about their ordinary lives. (... ) Also, I want them to know that theology is not a complex subject. ( ... ) I believe chitchat to be an important ingredient in theology. I have an abstract motive, which is to let them know that their emotions, concerns, activities which make up an integral part of their lives are all super ingredients for theology. ( . . . ) Lastly, taking a step further, I wish we could have more meetings like the ones we have now in our church and in our denomination.

A has embarked on another innovative mission to tackle the strict hierarchical formality looming over the church's entire culture. On the last Sunday of every month, he holds a special prayer service exclusively for YABs. During his service, he invites all of the attendees to come up close to the altar, the most sacred space in the church, to receive the Eucharist. He then starts his sermon without even a lectern. He says this is one form of worship service where YABs are placed in the center and respected and his way of tackling the stereotypical hierarchy dominating the church's culture.

One major change that has recently taken place at SAC is one of the YAB members was elected and accepted as a church committee member. Evidently this change is the fruit of YABs' efforts to secure a seat for representing YABs in the church committee, in addition to paving the way for a democratic decision-making process to be established within the church community. Undoubtedly, such bold steps taken to usher in new change will have a positive impact on the growth of YAB memberships in the SAC congregation. All of these efforts have had a positive impact and, as a result, SAC witnessed the declining trend of its YAB members turn around, as shown in Table 3.

Next is the survey finding on MDCC. In general, MDCC has concerns about the falling number of YABs and its implications to a certain extent. However, the phenomenon is not grave enough for its administrators to actively seek for innovative solutions. All of the participants to the interview unanimously stressed the efforts they have exerted in developing new ideas and implementing innovative measures. However, most of their innovations are based on conventional educational methods or solutions that emphasize the value of Catholic faith and the importance of communal life. $\mathbf{B}$, who is in charge of the middle and high school youth group, states the following:

15 For the idea of Theological Chatter, A was inspired by an American pastoral practice called 'Tap Theology' in the 1980s. There were, at that time, some Christian priests who gave their speeches and discussions in informal places like pubs or restaurants. The 'Tap' in the name literally means the lever used to pour draught beer. 
It is important to help people experience the love of God. Ultimately, we firmly believe God's love will make people come back to their faith. Accordingly, as for our given duty, we need to show and help the young people experience what it means to live in the love of God. ( ... ) We are trying to come up with alternative programs to help young people approach faith more easily. Moreover, we are looking for ways to teach young people about the meaning of 'sanctity of life.'16

A, who serves as the Director for Youth Ministry Department at Seoul Archdiocese, also states the following:

The program for leading youth to their faith and church includes encouraging them to not forget important religious values and making them understand the teachings of the church so that they realize they have an entire lifetime to get to know God.

All of these answers reflect confessional and doctrinal perspectives and stances based on Catholic faith and tradition. $\mathrm{C}$, the leader in charge of the YABs group at MDCC, has a similar opinion:

The most important thing is to sympathize with their hardships, converse with them, help them get over those hardships with faith. The most important thing is for them to receive consolation and hope from church and through the words and love of Jesus.

This position has led to a lack of willingness to retain and attract YABs. Therefore it becomes necessary to actively seek for programs filled with innovative ideas. To this end, $\mathbf{C}$ says the following:

Creative innovation eventually comes down to a methodological problem. The important thing is how much the church pays attention and listens to the voices of the young people fundamentally. Without being conscious of this dimension, any creative innovative events will only have short-term effects. ( ... ) So, the most important thing is adopting a life of faith. Youths should come to mass, learn the truth inside the scripture and we should help them live a life of a believer that prays and lives a faithful life.

Thus, even if they recognize the need for innovative solutions, practical measures devised to address this need tend not to escape the boundaries of the traditional paradigm set by the teachings of the Catholic faith. In fact, there are several ongoing youth programs run by Catholic churches. For example, the World Youth Day is organized by the Catholic Church, the Korea Youth Day is organized by the Korean Catholic Church, the Catholic youth bible camp, and elective camps. In recent years, new experiments have been conducted to attract youths' interest by organizing youth-specialized churches in cities including Suwon, Daegu and so on. In these churches all of the church members are young people. While these programs for youths as well as other new experiments appear to be formally 'innovative,' their contents and practices continue to dwell in the confessional traditions and doctrines of the Catholic faith.

What about the Buddhist temple, BBT? Like other religious congregations, BBT is concerned about the declining trend in YAB membership and its implications. But BBT does not appear to consider this downward trend in numbers to be extremely serious, which may prevent its leadership from actively seeking innovative solutions. Nonetheless, A, the leader in charge of the YAB group, is optimistic about his temple and the future of Buddhism. There is a logical explanation to his position, as follows:

(Laughing) Yes, I don't look at the situation seriously. ( ... ) I am rather optimistic about the future of Buddhism. Although people in the $21 \mathrm{C}$ declare themselves to be atheists or living without a religion, as the number of jobs decrease and society fails to provide quality

16 The Seoul Archdiocese offers a board of life and environmental education, which focuses on themes and issues related to life and the environment from the perspective of the Catholic faith. 
welfare, people will feel a sense of loneliness. I am certain these people engulfed in feelings of loneliness will likely try to reach out to communities that are warm and welcoming, just like the Buddhist community. This is why I stay optimistic.

A sees Buddhism as a form of religion that best meets the demands of nature, that is, the stages of the human life cycle. For instance, the reason Buddhists who visit the temple to study and practice are mostly elderly seniors is because people tend to turn to Buddhism when looking back and reflecting on their past. Naturally, A believes that seats left empty in Buddhist temples as a growing number of YABs desert their faith will eventually be filled by the elderly worshippers, as has historically been the case with Buddhism.

Nevertheless, this has not stopped A from taking on a new experiment. He plans to reorganize the YABs group following the 'cell group' concept that some Korean Protestant churches have adopted for their pastoral ministry. He has named it 'Young Adult Group of 108 people,' which is drawn literally from the Buddhist concept of '108 passions.' He plans to divide the group into six small cell organizations, ${ }^{17}$ each of which will be composed of $18-20$ young adult members. He is hoping the small cell group will grow to be more efficient and dynamic. He envisions in the near future a group consisting of 100 to 120 YABs who will actively pursue a religious life as well as learn and discuss topics relating to faith and the Buddhist classics.

In short, based on the optimistic view of the cyclical rise and fall of Buddhism throughout history, the BBT appears to be hesitant in accepting the idea that today's changing religious environment is serious business. Similarly, BBT is somewhat concerned about the falling number of its YABs but is not so worried as to recognize the current situation to be a competition between religions. BBT's take on the current situation will not encourage its leadership to focus actively on seeking for creative innovations. Therefore, even though A proposed the idea of the 'Young Adult Group of 108 people,' he does not appear to be motivated enough to draw up practical solutions for retaining and attracting YABs in his faith.

What about CSD congregation? Their situation is quite dire. As noted above, over the past three to four decades, the number of YABs has fallen dramatically and many are skeptical about whether the YABs group will continue to exist. Needless to say, this pessimistic outlook has serious consequences for the group's future as well as for CSD. A, who works as the general secretary, expresses her feelings about the topic in the following way:

Personally, from a broader perspective, I think our temple will not choose to focus its attention solely on youths, their difficulties and problems they face. These are problems not only youths but society as a whole face, and as you said before, our society is severely polarized into economic classes of haves and have nots. Under these social circumstances, our teachings tell us to help the weak and empathize with their hardships but Cheondogyo presently is unable to do so. We realize this is a mission our central headquarters needs to pursue. However, we are unable to take on the task due to our difficult condition at the moment.

Evidently, there is neither future prospects for members of the YABs group nor a willingness on the part of the congregation to adopt innovative efforts in hopes of retaining and attracting youth to CSD. Not surprisingly, survey findings show that, among the five congregations examined, CSD is the most passive and conservative in terms of the congregation's response and challenges they are willing to take on to tackle their changing situation.

\section{Summary and Discussion}

We have examined competitive and innovative attempts made by five Seoul downtown congregations to resolve the critical issue of the growing number of YABs leaving their faith.

17 The number 'six' is also drawn from the 'six lights of Buddhism' or 'six teachings of Buddha'. 
Their decision to leave faith largely stems from their cynical and critical attitudes towards religion as they rethink their faiths. Overall, by the middle of the 2000s, the population of YABs belonging to each downtown congregation began to decline, with the exception of the group belonging to the Seoul Anglican Cathedral Church. The downward trend of the YABs population was seen throughout the religious congregational communities and likely reflects the changing religious environment observed on a global scale. In macroscopic terms, one can argue that the changing religious situations like, for e.g., the 'Spiritual But Not Religious' or 'Believing Without Belonging' groups have been affected by the postmodern cultural conditions associated with moral relativism, individualism, uncertainties, ambivalence, inauthenticity, free-market capitalism, and so on.

However, the downward trend also reflects a peculiar cultural disposition in Korean society that drives the Korean mindset to follow a specific 'form of life' characterized by the hierarchically-oriented collective behavior. This cultural disposition creates an unequal hierarchical authority structure between the clergy and the laity, between the elderly and the young, or between men and women in the congregational community. It usually leads to absence of 'mutual and democratic communication structure' in the congregation, preventing YABs from participating freely and actively in the congregational decision-making process.

Thus, this study holds on to the micro-level focus on the competitions between churches or congregations, rather than on such macro factors as the competitions between religions or denominations as emphasized in orthodox religious economies theory. This micro-level approach is also adopted to examine the cultural dispositions which persistently affect the undemocratic communication structure within the churches or congregations.

Bearing this in mind, we have analyzed why YABs leave congregations, how their congregations react to the declining situation of the YABs population, what kinds of innovative solutions their congregations seek and implement to retain and attract YABs, and whether such solutions are effective. Although each of the congregations takes the changing religious situation into serious account, there is variation in their reactions and solutions to the situation, depending on the congregation.

First of all, Seoul Anglican Cathedral is far more active in responding to the situation and implementing innovative solutions to it, compared with the other four congregations. SAC strongly believes that they could turn the situation into an opportunity, by and through which it can play an important religious role in the 21st century. It is a leader in actively seeking for innovative solutions.

A new innovative experiment is the 'Theological Chatter' program, which aims to retain and attract new and YABs to the congregation. So far it seems to be working. However, one concern may be that putting too much of the focus on YABs may cause the congregation to build the church on the exclusive preferences of YABs, thereby unintentionally excluding older-generation believers.

YPC's response to and recognition of the changing religious situations reflect well its 'moderate conservative' value orientation. The leaders of the YABs group regards such situations as 'Spiritual But Not Religious' or 'Believing without Belonging' seriously, but also view them as 'inauthentic' because they are a type of 'infant faith' that might lead to an 'egoistic and atomistic self,' and as such it becomes an 'undesirable and dangerous faith'. Thus, it does not lead them to view the situation as one of religious or congregational competition, and consequently they do not attempt to actively seek for creative innovations. In this respect, the Sketchbook program aims to help YABs develop the language of faith they are missing, rather than innovatively attempting to penetrate into the detrimental effects of the Confucian cultural disposition that has a bearing on the mismatch of faith language between generations.

Both MDCC and BBT are the same in terms of their responses to, and recognitions of, the changing religious situations, even though they respectively belong to different denominations. Both give attention to the decline of YABs numbers and the situation it implies, but regard the situations less seriously, such that both of them do not seek actively for innovative solutions to retain and attract YABs. It is chiefly because the leaders of the YABs group do not distance themselves from the conventional paradigm on the changing religious situations that they tend to minimize the very concerns of the 
next generation. That is, they feel that the disconnection will end, either when the young adults get older and have their own children, or when other, more 'conventional' YABs join the congregation and make up for the decline in numbers due to this disconnection, just as every flow has its ebb. This response seems to dismiss the dramatic technological, socio-cultural, and religious changes that have occurred over the last two to three decades and ignore the significant challenges facing the YABs in the 21st century.

On the other hand, the overall situation of CSD is quite dire as, over the past three to four decades, the number of YABs has fallen dramatically and there is pessimistic concern as to whether the YABs group will continue to exist. The serious problem facing YABs at CSD is that neither an analysis of, nor an alternative plan to, the present and future situation of YABs has been attempted, and that there is neither prospects for the future of the YABs group, nor innovative attempts to retain and attract YABs to the congregation. Among the five congregations, CSD is the most passive and conservative in this regard.

Regarding the cultural disposition variable, all of the focus group interviewees do acknowledge the existence of such cultural-emotional and linguistic dispositions as seniority-based rule, ageism, patriarchal rule, authoritarian attitudes, and so on inherited from the Confucian legacies. This disposition functions as a sort of barrier which prevents both newcomers and YABs from active involvement in congregational activities and from participating democratically in the decision-making process. It gives rise to the absence of an 'interactive and democratic communication structure' between generations within the congregations. These elements are quite distinctive among most congregations. Of the five congregations, SAC is most actively involved in attempting to cultivate democratic intergenerational relationships in the congregation.

However, one commonality between all five of the congregations is the view of religious situations such as 'SBNR' or 'believing without belonging' as either 'undesirable' or 'inauthentic.' This means that they are still reluctant to recognize the significance of the current widespread spiritual concerns and movements, i.e., the 'spiritual turn,' which might lead to a radical transformation of the traditional concept of religion they hold on to, signifying a new form of religion.

Thus, strategies to retain and attract YABs, whether innovative or not, that the five downtown congregations have sought and implemented have not been very effective. It is chiefly because they all do not yet recognize the consistent decline of YABs as a consequence of the competitions between religions or congregations, which loom large, as well as the significance of 'spiritual turn' on a global scale. As a result, they still rely largely on the conventional and confessional methods rather than on seeking actively for any creative innovations. As mentioned already, SAC seems to have just entered the stage of actively and positively challenging this situation.

Funding: This research was supported by the John Templeton Foundation, under the research program (ID 48536), "Religious Competition and Creative Innovation". And the APC was also supported by them.

Conflicts of Interest: The author declares no conflict of interest.

\section{References}

Bellah, Robert Neelly, Richard Madsen, William M. Sullivan, Ann Swidler, and Steven M. Tipton. 1996. Habits of the Heart (Updated Edition with a New Intro.). Berkeley: University of Berkeley Press. First published 1985.

Bowen, John P. 2010. Growing Up Christian: Why Young People Stay in Church, Leave Church, and (Sometimes) Come Back to Church. Vancouver: Regent College Publishing.

Bush, Evelyn. 2010. Explaining Religious Market Failure: A Gendered Critique of the Religious Economies Model. Sociological Theory 28: 304-25. [CrossRef]

Chae, Byung Kwan. 2014. Confucian Protestant Churches Crossing the Pacific: A Sociological Study of Pre-Christian Asian Influences on Korean Immigrant Churches in America. Saarbrücken: Lap Lambert.

Chen, Jianlin. 2014. Deconstructing the Religious Free Market. Journal of Law, Religion and State 3: 1-24. [CrossRef]

Chu, Gyo-yoon. 2012. Hangug Hyeondaesa-eseoui Gatollig Gyohoe (The Catholic Church in the Modern History of Korea). Pastoral Information 5: 96-99. 
Collins-Mayo, Sylvia. 2012. Youth and Religion: An International Perspective. Zeitschrift für Religionspädagogik (Academic Journal of Religious Education) 11: 80-94.

Davie, Grace. 1994. The Religion in Britain since 1945: Believing without Belonging. Oxford: Blackwell.

Finke, Roger, and Rodney Stark. 1992. The Churching of America, 1776-1990: Winners and Losers in Our Religious Economy. New Brunswick: Rutgers University Press.

Fuller, Robert C. 2001. Spiritual, But Not Religious: Understanding Unchurched America. Oxford: Oxford University Press.

Fischer, Claude S., and Michael Hout. 2006. Century of Difference: How America Changed in the Last One Hundred Years. New York: Russell Sage Foundation.

Fulton, John. 2000. Young Catholics at the New Millennium: The Religion and Morality of Young Adults in Western Cultures. Dublin: University College Dublin Press.

Geertz, Clifford. 1993. The Interpretation of Cultures. London: Fontana.

Giordan, Giuseppe, ed. 2010. Annual Review of the Sociology of Religion 1: Youth and Religion. Leiden: Brill.

Heelas, Paul, and Linda Woodhead. 2005. The Spiritual Revolution: Why Religion in Giving Way to Spirituality. Oxford: Blackwell.

Hoge, Dean R. 2001. Young Adult Catholics: Religions in the Culture of Choice. Notre Dame: University of Notre Dame Press.

Holmes, Peter R. 2007. Spirituality: Some Disciplinary Perspectives. In A Sociology of Spirituality. Edited by Kieran Flanagan and Peter C. Jupp. Hampshire: Ashgate, pp. 23-42.

Inglehart, Ronald, and Pippa Norris. 2007. Why Didn't Religion Disappear? Reexamining the Secularization Thesis. In Cultures and Globalizations: Conflicts and Tensions. Edited by Helmut K. Anheier and Yudhishthir Isar. London: Sage, pp. 253-57.

Ivanhoe, Philip J., and Sungmoon Kim. 2016. Confucianism, A Habit of the Heart. New York: SUNY Press.

Jeon, Se-hoon. 2017. Cheongnyeon Sinjadeul-eun wae Gyohoeleul Tteonaneunga?: Gidoggyo Cheongnyeondeul-i Gyohoeleul Tteonaneun Iyu-e Daehan Negaji Gujo (Why Do Young Adult Believers Leave Church?: Four Structural Reasons Christian Youths Leave Church). In Hangug Gyohoe, Cheongnyeon-i Tteonago Issda (Korean Churches, Christian Youths Are Leaving). Edited by EYCK·NCCK Youth Commission. Seoul: Don-yeon, pp. 15-35.

Jung, Tai-sik. 2009. Gongjeog Jong-gyoloseoui Migug Gaesingyo Geunbonjuuiui Jeongchijeog Yeoghalgwa Hangye (Political Roles and Limitations of Fundamentalism as a Public Religion: Centered on the American Protestant Fundamentalism). The Korean Journal of Humanities and the Social Sciences 33: 40-67.

Kang, In-cheol. 2014. Jeong-gyobunli Ihuui Jong-gyowa Jeongchi (Religion and Politics Since the State-Religion Separation: Meaning and Dynamics). Democratic Society and Policy Studies 26: 139-67.

Kim, Sung Gun. 2005. Hangug sahoe-wa Gaesin-gyo (Korean Society and Protestantism). Chungju: Seowon University Press.

Kim, Sung Gun. 2017. The Place of Evangelical Protestantism in the Korean Public Sphere. Discourse 201: 143-70.

Kinnaman, David. 2011. You Lost Me: Why Young Christians Are Leaving Church and Rethinking Faith. Grand Rapids: Baker Books.

Krueger, Richard A., and Mary Anne Casey. 2008. Focus Groups: A Practical Guide for Applied Research, 4th ed. London: Sage.

Lechner, Frank J. 2007. Rational Choice and Religious Economies. In The Sage Handbook of the Sociology of Religion. Edited by James A. Beckford and N. Jay Demerath. London: Sage, pp. 81-96.

Lee, Man-yeol. 1989. Segye Gidoggyo sasang-ui Hangug Gidoggyo (The Korean Christianity in World Christian Thought). In Citizens' Forum on Korean History IV. Edited by Gi-baek Lee. Seoul: Iljogak, pp. 101-37.

Martin, David. 2001. Pentecostalism: The World They Parish (Religion and Modernity). London: Blackwell.

Mason, Michael, Andrew Singleton, and Ruth Webber. 2007. The Spirit of Generation Y: Young People's Spirituality in a Changing Australia. Mulgrave: John Garratt.

Norris, Pippa, and Roland Inglehart. 2004. Sacred and Secular: Religion and Politics Worldwide. Cambridge: Cambridge University Press.

Park, Young-shin, and Jae-young Jung. 2006. Hyeondae Hangugsahoe-wa Gidog-gyo (Modern Korean Society and Christianity). Seoul: Handl.

Pew Research Center. 2011. Global Christianity (Pew Forum on Religion \& Public Life). Washington: Pew-research Center. 
Putnam, Robert D., and David E. Campbell. 2012. American Grace: How Religion Divides and Unites Us. New York: Simon \& Schuster.

Rhinow, Malte. 2017. Seoul-Eseo mannan Luther (Luther met in Seoul). Seoul: Sinang-gwa Jiseongsa.

Song, Jae-ryong. 2013. Jonggyo-wa Sahoe baljeon (Religion and Social Development: with Reference to Roland Inglehart's Neo-secularization Theory). The Korean Journal of Humanities and the Social Sciences 37: 109-31.

Song, Jae-ryong. 2009. Hangugsahoeui Munhwagujo Teugseong-e Daehan Yeongu: Jeongeundaejeog Munhwagujo Teugseong-e daehan Yeongu (A Study on Traits of the Cultural Structure in Korean Society: Centered on the Pre-modern Cultural Habits). Discourse 201 12: 5-34. [CrossRef]

Song, Jae-ryong. 2002. Gajogjuui-wa Hangugsahoe-ui 'Salm-ui Yuhyeong' (Familism and 'Forms of Life' in Korean Society: Between Two Language Games). The Korean Journal of Humanities and the Social Sciences 26: 9-30.

Stark, Rodney. 2006. Economics of religion. In The Blackwell Companion to the Study of Religion. Edited by Robert A. Segal. Oxford: Blackwell, pp. 47-68.

Stark, Rodney, and Roger Finke. 2000. Acts of Faith: Explaining the Human Side of Religion. Berkeley: University of California Press.

Statistics Korea. 2017. 2015 Population and Housing Census Report; Seoul: Statistics Korea. Available online: http://kostat.go.kr (accessed on 5 December 2017).

Stolz, Jörg. 2006. Salvation Goods and Religious Markets: Integrating Rational Choice and Weberian Perspectives. Social Compass 53: 13-32. [CrossRef]

Wittgenstein, Ludwig. 1953. Philosophical Investigation. Oxford: Blackwell.

Woodhead, Linda. 2017. The Rise of "No Religion": Toward an Explanation. Sociology of Religion: A Quarterly Review 78: 1-16. [CrossRef]

Yang, Fenggang. 2006. The Red, Black, and Gray Markets of Religions in China. Social Compass 57: 93-112. [CrossRef]

Yang, Fenggang. 2012. Religion in China: Survival and Revival under Communist Rule. Oxford: Oxford University Press.

Yi, Jungyeon. 2014. Dosihwa wa Jong-gyo Sijang (Urbanization and Religious Market: A Case Study on Protestant Churches in Changsin-dong, 1960s-2000s). Economy and Society 101: 226-57.

Yoo, Kwangsuk. 2014. Jong-gyosijang-ui ihae (Understanding of Religious Market). Seoul: Dasan.

(C) 2019 by the author. Licensee MDPI, Basel, Switzerland. This article is an open access article distributed under the terms and conditions of the Creative Commons Attribution (CC BY) license (http://creativecommons.org/licenses/by/4.0/). 